A

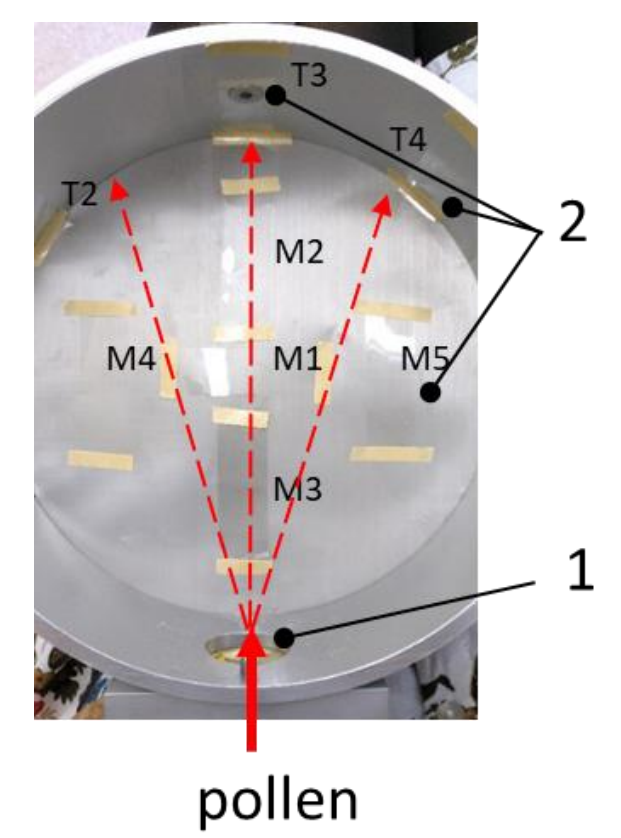

B

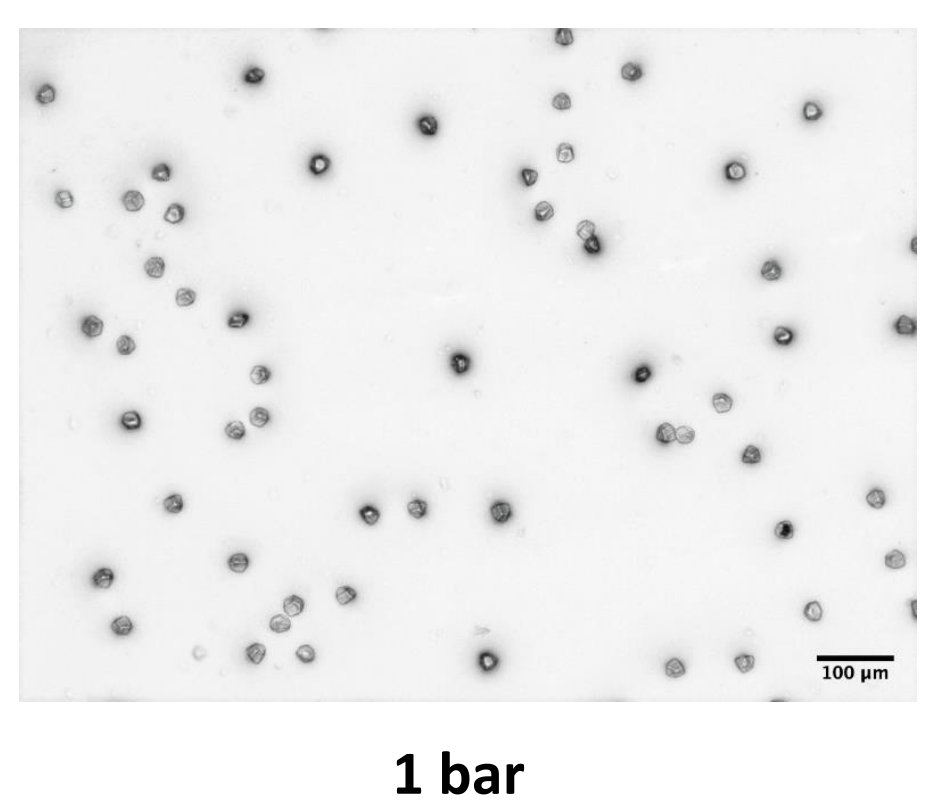

- $\overline{100 \mu m}$

\section{5 bar}

